\title{
REFORMA ADMINISTRATIVA \\ (primeiras impressões)
}

1. Administração Pública na reforma administrativa (EC n.19/98) - 2 . Motivos determinantes da Reforma administrativa - 3. Linhas gerais da Reforma Administrativa - 4. Reforma administrativa e modelo gerencial de Administração Pública - 5. O insucesso das reformas administrativas - 5.1 Supervalorização do elemento institucional - 5.2 Mentalidade dos destinatários dos preceitos constitucionais reformados- 5.3 Reforma da Constituição como saida para todos os males da Administração Pública - 6. Reforma administrativa, interpretação constitucional e a missão dos juristas - 7. Disposiçōes transitórias da EC n.19/98 - 7.1 Prazo para as entidades da administração indireta revisarem seus estatutos 7.2 Prazo para a elaboração de lei do usuário de serviços públicos 7.3 Proibição de excessos das espécies remuneratórias e direito adquirido - 7.4 Prazo para apresentação do projeto de lei complementar - 7.5 Direitos, vantagens e proibições dos servidores - 7.6 Servidores da carreira policial militar e grau hierárquico - 7.7 Servidores civis e seu aproveitamento - 8. Dispositivos constitucionais reformulados

\section{Administração Pública na reforma administrativa (EC n.19/98)}

A Emenda Constitucional n.19, de 4 de junho de 1998, trouxe a reforma administrativa, atingindo inúmeros dispositivos, alterando-lhes não só a redação, mas produzindo profundas consequiências na vida da Administração Pública.

Nesse desiderato, a referida mudança formal repercutiu na vida dos agentes públicos, alterando, sobremaneira, o regime administrativo do Estado brasileiro, seus princípios e normas, além de propor o controle das despesas e finanças públicas, para influenciar o custeio de atividades a cargo do Distrito Federal.

* Professor de Direito Constitucional. Mestre e Doutorando em Direito do Estado (PUC/SP). Membro da Comissão Permanente de Direito Constitucional do Instituto dos Advogados Brasileiros.

R. Dir. Adm.,

Rio de Janeiro, 214: 69-98,

out./dez. 1998 
Os motivos determinantes da Reforma administrativa podem ser sentidos nos seguintes excertos da Mensagem $n^{2} 886$, de 1995, encaminhada ao Excelentíssimo Senhor Presidente da República:

$\left.1^{2}\right)$ "A crise do Estado está na raiz do período de prolongada estagnação econômica que o Brasil experimentou nos últimos quinze anos. Nas suas múltiplas facetas, esta crise se manifestou como crise fiscal, crise do modo de intervenção do Estado na economia e crise do próprio aparelho estatal. No que diz respeito a esta última dimensão, a capacidade de ação administrativa do Estado se deteriorou, enquanto prevalecia um enfoque equivocado que levou ao desmonte do aparelho estatal e aos desprestígio de sua burocracia” (Mensagem $\mathrm{n}^{\circ} 886 / 95$, p.24);

$2^{\circ}$ ) "Para este Governo, a reforma administrativa é componente indissociável do conjunto de mudanças constitucionais que está propondo à sociedade. São mudanças que conduzirão à reestruturação do Estado e a redefinição do seu papel e da sua forma de atuação, para que se possa alcançar um equacionamento consistente e duradouro da crise" (Mensagem $\mathrm{n}^{\mathfrak{Q}}$ 886/95, p.25);

$3^{\text {9 }) ~ " N o ~ d i f i ́ c i l ~ c o n t e x t o ~ d o ~ r e t o r n o ~ a ̀ ~ d e m o c r a c i a, ~ q u e ~ e m ~ n o s s o ~ p a i ́ s ~ f o i ~ s i m u l-~}$ tâneo à crise financeira do Estado, a Constituição de 1988 corporificou uma concepção de administração pública verticalizada, hierárquica, rígida, que favoreceu a proliferação de controles muitas vezes desnecessários. Cumpre agora, reavaliar algumas das opções e modelos adotados, assimilando novos conceitos que reorientem a ação estatal em direção à eficiência e à qualidade dos serviços prestados ao cidadão" (Mensagem no 886/95, p.25);

$4^{\mathrm{Q}}$ ) “A revisão de dispositivos constitucionais e inúmeras outras mudanças na esfera jurídico-legal que a acompanharão, estão direcionadas para o delineamento de condições propícias à implantação de novos formatos organizacionais e institucionais, à revisão de rotinas e procedimentos e à substituição dos controles formais pela avaliação permanente de resultados" (Mensagem $\mathrm{n}^{0} 886 / 95$, p.25);

$5^{\mathrm{o}}$ ) "Coerente com estes propósitos, Sr. Presidente, acreditamos que as emendas constitucionais ora apresentadas venham contribuir decisivamente para o revigoramento da administração pública, com impactos positivos sobre o conjunto da ação governamental e sobre a sociedade" (Mensagem $\mathrm{n}^{9} 886 / 95, \mathrm{p} .25$ );

$6^{0}$ ) "A reforma constitucional permitirá a implantação de um novo desenho estrutural na Administração Pública brasileira que contemplará a diferenciação e a inovação no tratamento de estruturas, formas jurídicas e métodos de gestão e de controle, particularmente no que tange ao regime jurídico dos servidores, aos mecanismos de recrutamento de quadros e a política remuneratória" (Mensagem $\mathrm{n}^{\mathbf{Q}}$ 886/95, p.26);

$\left.7^{0}\right)$ "Em relação ao servidor público, não se intenciona penalizá-lo ou suprimir direitos, mas atualizar dispositivos legais, remover excessos e, sobretudo, propiciar condições à introdução de novas formas de gestão que valorizem a sua profissionalização. Nesse sentido, ressaltam-se os seguintes resultados esperados: recuperar o respeito e a imagem do servidor perante a sociedade; estimular o seu desenvolvimento profissional; melhorar as condições de trabalho" (Mensagem $n^{2} 886 / 95$, p. 26). 
Seriam esses alguns dos motivos que, conforme os proponentes da EC n.19/98, justificariam a necessidade de se mudar a concepção de Estado, superando o tradicional vezo burocrático que vem transformando a Administração num obstáculo ao crescimento do País.

\section{Linhas gerais da Reforma Administrativa}

Em linhas gerais, a mudança formal à Carta de 1988 interferiu na admissão de pessoal, na política remuneratória, na estabilidade e na descentralização de funções das entidades administrativas.

Dentre outros aspectos, técnicas de gestão foram aplicadas às alterações constitucionais, sob o argumento de que tal medida melhoraria a eficiência e o desempenho do servidor público.

\section{Reforma administrativa e modelo gerencial de Administração Püblica}

A EC n.19/98 acompanhou a tendência de outros Estados contemporâneos, no sentido de propor alterações formais nos princípios e normas que regulamentam a Administração Pública.

Assim, a reforma administrativa não é algo exclusivo do Brasil, mas sim uma experiência universal, que vem sendo adotada em diversas partes do mundo (Cf.: Jorge Reinaldo Vanossi. La reforma constitucional y la administración pública. Relatório en las Jornadas Nacionales de Derecho Administrativo. Santa Fé, Instituto de Derecho Administrativo de la Universidad Nacional del Litoral, 1974; José Luis Palazzo, Domingo Juan Sesín e Victor Armando Rolón. La transformación del Estado. Buenos Aires, Ediciones Depalma, 1992).

Dentre os inúmeros aspectos comuns às reformas administrativas, está a implantação do modelo gerencial em substituição ao modelo burocrático de Estado, erigindo-se o que pode ser denominado de Administração Pública de resultados. Esta, por sua vez, lastreia-se num modelo gerencial, visando aumentar a efetividade dos serviços prestados à população, bem como definir o núcleo estratégico do Estado, através da delimitação de políticas públicas e do equacionamento financeiro da máquina administrativa. Nesse último aspecto, tem em vista o equilíbrio da receita e da despesa.

Com tal medida, intenta-se acabar com o amparato de privilégios, vertidos em um "Código do fracasso", donde sobressai a máxima de Roberto Dromi: "não pode; em caso de dúvida, abstenha-se; se é urgente, espere; sempre é mais prudente não fazer nada" (In:Roberto Dromi.Derecho Administrativo. 4.ed. Buenos Aires, Ediciones Ciudad Argentina, 1995, p.35).

Last but not least, os encarregados de mudar a Constituição colocaram o carro na frente dos bois, cometendo, mais uma vez, equívoco lamentável, pois não perceberam que a ênfase dada ao aspecto institucional-legal não é a única solução capaz de trazer benefícios. Do ângulo financeiro apertaram o cinto das estatais, o que, a 
um primeiro momento, parece ser positivo. Acreditaram, contudo, que passando do modelo burocrático de Estado para o gerencial, poderiam equacionar a receita, eliminando as despesas e obtendo resultados. Em tese, a concepção de autonomia gerencial afigura-se salutar. Do ponto de vista da viabilidade ou realização concreta o problema é outro, porque o instrumento de realização do modelo gerencial é o contrato de gestão. Todavia, este contrato, cujo fundamento é dinamizar as parcerias solidárias, é uma incógnita, desafiando a argúcia dos juristas e a enorme criatividade das entidades político-administrativas.

\section{O insucesso das reformas administrativas}

Estaria o Brasil preparado para receber o influxo das inovações propostas, passando do modelo burocrático para o gerencial de Estado? Os Poderes Públicos têm como cumprir o ambicioso projeto de resultados instituído pela EC 19/98? São os depositários do poder constituinte derivado que podem satisfazer todas as solicitações manifestadas, sob o argumento de que a sua ação serviria para reavaliar as rotinas organizacionais e institucionais da Administração Pública?

Deixamos à meditação do leitor essas perguntas mínimas, extraídas do vasto universo de indagações suscitadas da EC n.19/98.

A nosso ver, três são as razões primordias por que as reformas administrativas não logram êxito:

$1^{\text {a })}$ supervalorização do elemento institucional;

$2^{\mathrm{a}}$ ) mentalidade dos destinatários diretos e indiretos dos preceitos constitucionais reformados;

$\left.3^{\mathbf{a}}\right)$ suposição de que reformas constitucionais constituem o remédio para todos os males da Administração Pública.

\subsection{Supervalorização do elemento institucional}

Juan Prats Catala, na introdução à obra de Michel Crozier, questiona a razão pela qual as reformas administrativas são fadadas ao fracasso. Segundo ele, a concepção tecnocrática conduz à pretensão de um diagnóstico completo dos males da Administração, ignorando a prevalência de recursos e os condicionamentos sobre os fins, dentre os quais a maneira como os funcionários e os cidadãos vivem. Daí asseverar que as reformas não podem se basear apenas em textos legais ou reorganizações estruturais (In:Michel Crozier. No se cambia la sociedad por decreto. Madrid, Enap, 1971, p.3-4).

Realmente, a tentativa de se modernizar a Administração, no intuito de torná-la eficiente, ágil, rápida, livre de corrupções, dotada de economicidade, apta a gerar resultados e vencer a burocracia, gerenciando recursos públicos e priorizando a publicidade ao invés do segredo, constitui ideário que nobilita o indivíduo, o qual é concebido não como um mero súdito em busca de favores e comiserações, mas um cidadão, apto a exercer direitos constitucionais e cumprir deveres assegurados pela ordem jurídica, dentre os quais o de pagar impostos, taxas, contribuições de melhoria 
etc. Acontece, porém, que o aspecto institucional-legal não é o único capaz de trazer benefícios à Nação, porque ao lado dele existem outras variáveis, sendo a principal delas a incúria dos Governantes, que, valendo-se de ilusórias promessas eleitoreiras periódicas, atribuem às leis o encargo impossível de mudar a sociedade.

\subsection{Mentalidade dos destinatários dos preceitos constitucionais reformados}

Eis o maior de todos os problemas ligados à realização concreta dos preceitos decorrentes de reformas administrativas: a mentalidade dos destinatários diretos $\mathrm{e}$ indiretos dos preceitos constitucionais positivados, em última análise dos operadores do direito, que, olvidando e rechaçando as mudanças operadas no Texto Maior, mantêm-se numa postura de retaguarda, de crítica exacerbada ao produto constitucional reformado.

Sem dúvida, interpretar a lei é algo distinto de se ter uma postura de bloqueio, de aversão ao novo. Ao contrário, a atividade interpretativa é um ato volitivo associado a um ato cognoscitivo, cabendo ao interprete estabelecer os limites do conhecimento jurídico válido, aferindo técnicas de raciocínio isentas de paixões ou inclinações de cunho pessoal (Cf.: Uadi Lammêgo Bulos. Manual de Interpretação Constitucional. São Paulo, Saraiva, 1997, p.2). O objetivo da interpretação é eliminar conflitos, pondo termo aos 'contrastes' inerentes à linguagem prescritiva do legislador. Interpretar, pois, é equacionar dilemas, jamais recrudescê-los. Sem essa postura, as decisões jurídicas não se consumam, nem, tampouco, são criadas as condições para que sejam tomadas. Estamos diante do relevante papel desempenhado pela função social da dogmática jurídica e a sua notável importância para o equacionamento de problemas concretos (Cf.: J. W. Ehrlich. The lost art of Cross-Examination or perjury anyone? With an introduction by Percy Foreman. New York, Barnes \& Noble Books, 1993).

\subsection{Reforma da Constituição como saída para todos os males da Administração Pública}

O último motivo pelo qual as reformas administrativas fracassam se assenta na crença de que reformas constitucionais possuem o condão de sanar os males da Administração Pública. Pensar desse modo, porém, é cometer exagero, porque mudanças formais, contínuas e simultâneas, visando renovar a fisionomia geral do Estado brasileiro, não operam, a princípio, efeitos imediatos, haja vista o fato de dependerem de atos legislativos e administrativos para fazê-las figurar entre as regras vivas. Dai a necessidade da colaboração do Executivo e do Legislativo, no sentido de não retardarem as medidas cabíveis no caso, nada obstante a constatação de que quase sempre falham, pois falta-lhes energia e clarividência.

Pondere-se, tão-somente, que mudar uma Constituição, através do recurso instituído da emenda, não é uma competência normal, corriqueira, fácil. Não é algo sub-reptício, servindo para resolver todos os problemas concretos. Ao invés, a ação 
do poder de reforma constitucional exercita-se num círculo de atividades reguladas e delimitadas.

Por isso, nem todas as reclamaçōes formuladas podem ser acolhidas. E deve ser assim, porque alterar a estrutura das normas supremas do Estado não é o mesmo que criar leis ordinárias, resolver processos, realizar atos administrativos. Trata-se de uma faculdade excepcional, extraordinária!

Sobremais, a Constituição é um meio e nunca um fim em si mesma. Não podemos alimentar a ilusão de que a força operante das normas constitucionais podem evoluir a conjuntura social. A situação é outra: os preceitos constitucionais servem para ordenar a realidade circundante a depender da interpretação que se lhes atribuam. Todavia, não são emendas, inoportunas e inviáveis, com promessas teóricas de fácil equacionamento, que trarão uma suposta 'felicidade nacional'.

Jorge Reinaldo Vanossi transmitiu lição lapidar. Conforme ensinou, dois problemas surgem quando falamos em reforma constitucional: $1^{2}$ ) em que sentido se fará a mudança; e $2^{\mathfrak{Q}}$ ) como o órgão reformador deverá comportar-se perante ela (Teoría Constitucional. Tomo I, Buenos Aires, Depalma, 1975, p.508).

$\mathrm{E}$, para se reformular o texto de uma Constituição, urge, a priori, se chegar a um acordo sobre várias questões, as quais se confluem em três itens distintos, porém complementares:

$1^{\mathrm{a}}$ : que é que se quer reformar;

$2^{\mathrm{a}}$ : que é que se deve reformar;

3a: que é que, presumivelmente, se pode reformar.

Desse modo, não é mera empreitada mudar textos constitucionais. $O$ constituinte derivado brasileiro, de um modo geral, se preocupa em fazer reformas, esquecendo-se do modo como elas devem ser concebidas.

Tudo isso se aplica à reforma administrativa, que trouxe preceitos de difícil realização prática, pois a mentalidade implantada no Brasil não enseja a adoção do modelo gerencial de Estado. O tempo irá confirmar a assertiva. Nada melhor do que a força dos fatos, submetidos ao teste vivencial da experiência.

\section{Reforma administrativa, interpretação constitucional e a missão dos juristas}

O que se acaba de expor, contudo, muito mais do que um campo aberto à crítica velada, equivale a um convite para a meditação dos juristas. Eles, mais do que nunca, podem contribuir, interpretando os preceitos constitucionais reformados, sacandolhes o alcance e o conteúdo, ainda que a reforma administrativa não tenha sido o caminho mais adequado para obter-se a superação das dificuldades nacionais.

Certamente, interpretar preceitos constitucionais não é apenas criticá-los. Ao invés, é desvendar-lhes a trama normativa, extraindo o que contêm de mais profundo e positivo, ainda que o produto normado seja confuso, fruto dos embates de interesse antagônicos de variadíssima gama. $\mathrm{O}$ intérprete deve, antes de tudo, desconfiar de si mesmo, para não se precipitar, restando-lhe avaliar os motivos favoráveis ou contrários, que o autorizam a interpretar, verificando as teses e as idéias preconcebidas que o inclinam nesta ou naquela vertente. 
A Administração Pública alcançou na Constituição brasileira vigente posto de destaque, porquanto o constituinte lhe deu tratamento amplo. Esta situação foi mantida pela EC n.19/98, a qual modificou o texto originário. Quanto à última, recomenda-se que seja interpretada com isenção de ânimo e espírito de abertura, sem o vício da antipatia, relevando-se o caráter precipitado com que foi lançada ao mundo jurídico, numa época em que o Brasil não estava preparado para receber o influxo do modelo formalmente implantado.

\section{Disposições transitórias da EC n.19/98}

A EC n.19/98, trouxe disposições transitórias, as quais valem ser transcritas, antes de adentrarmos nas anotações seguintes. Nesse ínterim, vale destacar os assuntos que nelas contêm, no intuito de facilitar-lhes a apreensão.

\subsection{Prazo para as entidades da administração indireta revisarem seus estatutos}

Art. 26 da EC n.19/98, "No prazo de 2 (dois) anos da promulgação desta Emenda, as entidades da administração indireta terão seus estatutos revistos quanto à respectiva natureza jurídica, tendo em conta a finalidade e as competências efetivamente executadas".

7.2 Prazo para a elaboração de lei do usuário de serviços públicos

Art. 27 da EC n.19/98, "O Congresso Nacional, dentro de 120 (cento e vinte) dias da promulgação desta Emenda, elaborará lei de defesa do usuário de serviços públicos".

7.3 Proibição de excessos das espécies remuneratórias e direito adquirido

Art. 29 da EC n.19/98, "Os subsídios, vencimentos, remuneração, proventos da aposentadoria e pensões e quaisquer outras espécies remuneratórias adequar-se-ão, a partir da promulgação desta Emenda, aos limites decorrentes da Constituição Federal, não se admitindo a percepção de excesso a qualquer título".

Nesse dispositivo, os depositários do poder reformador perderam uma grande oportunidade para ressalvarem, expressamente, as situações envolvendo direito adquirido (art. $5^{0}, \mathrm{XXXVI)}$.

A manutenção dos direitos já incorporados, em definitivo, ao patrimônio individual dos sujeitos, convém ser resguardada, em nome do primado implícito da segurança jurídica, bem como os direitos e garantias fudamentais consagrados pela própria Constituição. 


\subsection{Prazo para apresentaçāo do projeto de lei complementar}

Art. 30 da EC n.19/98, "O projeto de lei complementar a que se refere o art. 163 da Constituição Federal será apresentado pelo Poder Executivo ao Congresso Nacional no prazo máximo de 180 (cento e oitenta) dias da promulgação desta Emenda".

\subsection{Direitos, vantagens e proibiçōes dos servidores}

Art. 31, caput, da EC n.19/98, "Os servidores públicos federais da administração direta e indireta, os servidores municipais e os integrantes da carreira policial militar dos ex-Territórios Federais do Amapá e de Roraima, que comprovadamente encontravam-se no exercício regular de suas funções prestando serviços àqueles ex-Territórios na data em que foram transformados em Estados; os policiais militares que tenham sido admitidos por força de lei federal, custeados pela União; $e$, ainda, os servidores civis nesses Estados com vínculo funcional já reconhecido pela União, constituirāo quadro em extinção da administração federal, assegurados os direitos e vantagens inerentes aos seus servidores, vedado o pagamento, a qualquer título, de diferenças remuneratórias.

\subsection{Servidores da carreira policial militar e grau hierárquico}

Art. $31, \S 1^{\circ}$, da EC n.19/98, Os servidores da carreira policial militar continuarão prestando serviços aos respectivos Estados, na condição de cedidos, submetidos às disposições legais e regulamentares a que estão sujeitas as corporações das respectivas Polícias Militares, observadas as atribuições de função compativeis com seu grau hierárquico.

\subsection{Servidores civis e seu aproveitamento}

Art. $31, \S 2^{\underline{0}}$, da EC n.19/98, Os servidores civis continuarão prestando serviços aos respectivos Estados, na condição de cedidos, até seu aproveitamento em órgão da administração federal".

\section{Dispositivos constitucionais reformulados}

Art. 37. A administração pública direta $e$ indireta de qualquer dos Poderes da União, dos Estados, do Distrito Federal e dos Municípios obedecerá aos princípios de legalidade, impessoalidade, moralidade, publicidade e eficiência e, também, ao seguinte:

O dispositivo possui a seguinte redação originária: Art. 37. A administração pública direta, indireta ou fundacional, de qualquer dos Poderes da União, dos 
Estados, do Distrito Federal e dos Municipios obedecerá aos princípios de legalidade, impessoalidade, moralidade, publicidade e, também, ao seguinte:

\section{Princípio da eficiência}

O princípio da eficiência proveio em nosso ordenamento constitucional da EC n.19/98, que o incorporou ao texto primitivo da Constituição de 1988 (art. 37, caput). Ele já existia na legislação infraconstitucional, a exemplo do Decreto-lei 200/67 (arts.13 e 25, V), da Lei de Concessões e Permissões (Lei 8.987/95, arts. $6^{\mathbf{0}}$ e $7^{\mathbf{0}}$ ) e

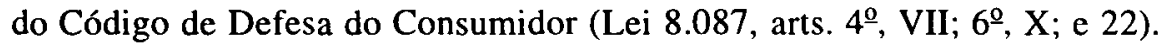

A inserção do princípio da eficiência, ao lado dos vetores clássicos da legalidade, impessoalidade, moralidade e publicidade calcou-se no argumento de que o aparelho estatal deve se revelar apto para gerar benefícios, prestando serviços à sociedade $\mathrm{e}$ respeitando o cidadão contribuinte.

Eficiência, 'voz' que adjetiva o princípio em análise, traduz idéia de presteza, rendimento funcional, responsabilidade no cumprimento de deveres impostos a todo e qualquer agente público. Seu objetivo é claro: a obtenção de resultados positivos no exercício dos serviços públicos, satisfazendo as necessidades básicas dos administrados.

Princípio moderno da função administrativa, haurido da doutrina italiana, a eficiência equivale a um reclamo contra a burocracia estatal, sendo uma tentativa para combater a malversação dos recursos públicos, a falta de planejamento, os erros repetidos através de práticas gravosas.

A interpretação do princípio contitucional da eficiência convém proceder em sentido amplo, precisamente para abranger as condutas 'burocrática' e 'tecnocrática' . A primeira - a 'burocrática' - é aquela que se insurge contra as leis, os procedimentos corretos, evitando controles, porque é avessa a todas as formas imediatas e rápidas de se resolver problemas. Já a segunda - a 'tecnocrática' — volta-se contra a qualidade final dos serviços que podem ser prestados para a satisfação do usuário.

Com efeito, a eficiência e a eficácia da Administração Pública são faces de uma mesma moeda. Enquanto a eficiência colima resolver problemas, através do cumprimento de deveres, voltados para reduzir custos, a eficácia - palavra polissêmica que logra vários sentidos - tem em vista a produção de alternativas racionais e criativas, para obter lucros e resultados positivos. Ambos, compreendidos como instrumentos de gerenciamento de crises, podem servir para a implantação de um governo empreendedor, que gera receitas e diminui as despesas. Sobre a eficiência e a eficácia, disse Roberto Dromi, ao analisar problemas ligados à licitação pública: "El princípio da la eficácia, en nuestro ordenamiento, alcanza un significado muy importante. Hoy constitue también un imperativo constitucional, que ha dado que tipifiquemos a la Constitución de eficientista, en el sentido de que en ella se encuentran las virtudes para un gobierno y un control eficientes" (Licitación pública, Buenos Aires, Ciudad Argentina, 1995, p.499).

O princípio constitucional da eficiência é de aplicação imediata. Seus efeitos são plenos, porque não há necessidade de norma infraconstitucional para implementá-lo. 
A aplicação do princípio constitucional da eficiência possui o condão de gerar mudanças no comportamento funcional da Administração. Todavia, isto depende da mentalidade dos administradores e dos próprios administrados. Na matéria dos contratos administrativos e das licitações, por exemplo, a observância do pórtico poderá ensejar apuração de responsabilidades. Augustín Gordillo percebeu bem isso, aduzindo que "Así como hace ele dictamen jurídico y el informe técnico suficiente y razonable que justifiquen prescindir de la licitación pública en el caso de urgencia, así también la eficiencia de la contratación deberá ser materia de análisis específico mediante los informes que produzirán los organismos técnicos permanentes de administración, y por el dictamen letrado igualmente del servicio permanente de asesoramiento juridico. Desde luego, incurrirá en responsabilidad personal el funcionario que en funciones de asesoriamento letrado olvide analizar y recomendar lo pertinente en este nuevo elemento proprio de legalidad de contratación administrativa (Tratado de Derecho Administrativo. Parte gerneral. Tomo I. Fundación de Derecho Administrativo, Buenos Aires, 1997, p.16).

O vetor constitucional da eficiência serve para atenuar o formalismo exacerbado. Nesse ponto, irmana-se com o princípio da razoabilidade, no sentido de que funcionará para balizar a conduta do legislador, mas sem ferir a lei. Pretende-se alcançar, com tal prática, a proporcionalidade, proibindo-se excessos (Cf.: Raquel Denize Stumm. Princípio da proporcionalidade no Direito Constitucional Brasileiro. Porto Alegre, Livraria do Advogado Editora, 1995; Suzana de Toledo Barros. O princípio da proporcionalidade e o controle de constitucionalidade das leis restritivas de direitos fundamentais. Brasília, Editora Brasília Jurídica, 1996).

Note-se que a eficiência é uma diretriz autônoma, não se colocando como subprincípio de nenhum outro primado, nem, muito menos, se contrapondo ao ditame da legalidade, fundamentalíssimo para a Administração, a qual não pode conviver com vínculos jurídicos formados ilicitamente. Quando se diz que a eficiência nutre relação com a proporcionalidade, é no sentido da busca de resultados, servindo de controle para certas medidas legislativas, de cunho burocrático e formalista, as quais acabam reacaindo num legalismo estéril que percorre os diversos níveis da Administração Pública, sem trazer qualquer benefício a ela e aos administrados.

Nessa perspectiva, o princípio constitucional da eficiência poderá contribuir, ainda, para o fortalecimento da teoria da convalidação do ato administrativo, a qual procura justificar o saneamento da invalidade de um ato, legitimando seus efeitos pretéritos.

I-os cargos, empregos e funções públicas são acessiveis aos brasileiros que preencham os requisitos estabelecidos em lei, assim como aos estrangeiros, na forma da lei;

Dispositivo originário: $I$ - os cargos, empregos e funções públicas são acessiveis aos brasileiros que preencham os requisitos estabelecidos em lei.

Acessibilidade aos estrangeiros

A partir da EC n.19/98, o princípio constitucional da acessibilidade dirigiu-se, também, aos estrangeiros. Decorrência disso: não mais vigoram determinadas normas 
infraconstitucionais, a exemplo daquela prevista no art. 5o, inc. I, da Lei 8.212/90, que considera requisito para a investidura em cargo público a nacionalidade brasileira.

Tal medida suspendeu a exigência da nacionalidade brasileira como requisito prévio para o acesso a cargos, empregos e funções públicas, sendo, em verdade, um complemento à EC n.11/95, que facultou às Universidades admitir professores, técnicos e cientistas estrangeiros, nos termos da lei (art. 207, $\S 1^{\mathbf{0}}$ ).

Ficará a lei incumbida de ditar os critérios aferidores do benefício, que teve como meta prestigiar instituições de ensino e de pesquisa, que se ressentiam das amarras constitucionais, as quais impediam a atração de profissionais estrangeiros especializados para a ocupação de atividades permanentes.

Parece-nos que tal diretriz pode ser aplicada aos Países componentes do Mercosul. Há uma espécie de reciprocidade, a qual autoriza a iniciativa louvável de universalização do conhecimento, favorecendo o avanço tecnológico e científico, em prol do progresso dos povos.

II - a investidura em cargo ou emprego público depende de aprovação prévia em concurso público de provas ou de provas e títulos, de acordo com a natureza e a complexidade do cargo ou emprego, na forma prevista em lei, ressalvadas as nomeações para cargo em comissão declarado em lei de livre nomeação e exoneração;

Dispositivo originário: II - a investidura em cargo ou emprego público depende de aprovação prévia em concurso público de provas ou de provas e titulos, ressalvadas as nomeações para cargo em comissão declarado em lei de livre nomeação e exoneração.

\section{Natureza e complexidade do cargo ou emprego}

A EC n.19/98 trouxe a ressalva de que o concurso público de provas ou de provas e títulos deverá considerar a natureza e a complexidade do cargo ou emprego, na forma da lei.

Advirta-se, desde logo, que a norma constitucional em epígrafe não é auto-aplicável, e, como tal, deverá esperar que o legislador ordinário se manifeste, detalhando os critérios aferidores da natureza e da complexidade do cargo ou emprego. Enquanto não sobrevier a legislação integradora do ditame, a matéria ficará sujeita à incidência do instituto da construção constitucional, a ser empreendida pelos juízes e Tribunais (Sobre construção constitucional: Uadi Lammêgo Bulos. Mutação Constitucional. São Paulo, Saraiva, 1997, p.141-167). Todavia, a lei superveniente, embora possa estipular técnicas avançadas de apuração do conhecimento nos processos seletivos, deverá respeitar o sistema de méritos, implantado pelo constituinte de 1988 . Sobremais, a competência para a sua expedição ficará a cargo dos entes políticos, que, pelo dispositivo constitucional, não têm prazo delimitado para fazê-lo.

O enunciado "de acordo com a natureza e a complexidade do cargo ou emprego" não pode servir de apanágio para a quebra da obrigatoriedade do concurso público 
de provas ou de provas e títulos. Logo, será inconstitucional a lei que flexibilizar o ritual dos concursos, independentemente da natureza, simples ou complexa, de determinado encargo. Poderá, no máximo, adaptar os métodos de avaliação ao perfil específico dos conhecimentos exigidos para cada cargo ou emprego, mas sem agredir o critério de escolha dos melhores e mais competentes, que demonstraram maior aptidão para o exercício de um dado mister.

É inegável que a frase "de acordo com a natureza e a complexidade do cargo ou emprego" não é das melhores, porque é vaga. Daí o relevante papel do intérprete da Constituição, o qual não deverá sacar da mensagem prescrita no dispositivo constitucional raciocínio compatível com a flexibilização do concurso público, violando a manifestação constituinte originária de 1988, que condicionou a investidura em cargo ou emprego público à aprovação prévia em concurso público de provas ou de provas e títulos. Conspurcar tal realidade é agredir o próprio princípio republicano, o qual não se compactua com a exclusão de um procedimento administrativo aberto a todo e qualquer interessado que preencha os critérios definidos em lei. Noutro sítio, a flexibilização do concurso público acabaria ferindo o pórtico da igualdade, porque a Constituição deu a possibilidade de que todos se increvam para participar de certames públicos, sem desequiparações, e sim através de critérios objetivos, previamente estabelecidos no edital de abertura, mediante os quais se medem a capacidade e o mérito dos concursandos.

Sem dúvida, continua em pleno vigor a Súmula 221 do TCU, que tem se mostrado atento para a o princípio constitucional da obrigatoriedade de aprovação prévia em concurso público de provas ou de provas e títulos, aplicável às paraestatais. Aliás, o Supremo Tribunal Federal tem alertado para o cumprimento do sistema de méritos, norteador de toda a Administração Pública brasileira, inclusive as paraestatais (STF, MS 21.322, DJ de 23.04.1993, p.6.921). O mesmo se diga em relação à jurisprudência firmada no sentido da aludida obrigatoriedade, bem como outros aspectos relacionados à matéria, e que continuam totalmente atuais perante a EC n.19/98: STF, RTJ 155:178; STF, RDA 190:150; STF, RDA 181:102; STF, RTJ 156:777; STF, RDA 187:176; STF, RTJ 154:45; STF, RTJ 152:79; STF, RTJ 146:139; $\mathrm{STF}, R T J$ 149:663; STF, RTJ 156:793; STF, RDA 197:127 etc.

$\mathrm{V}$ - as funções de confiança, exercidas exclusivamente por servidores ocupantes de cargo efetivo, e os cargos em comissão, a serem preenchidos por servidores de carreira nos casos, condições e percentuais mínimos previstos em lei, destinam-se apenas às atribuições de direção, chefia e assessoramento;

Dispositivo original: $V-$ os cargos em comissão e as funções de confiança serão exercidos, preferencialmente, por servidores ocupantes de cargo de carreira técnica ou profissional, nos casos e condições previstos em lei.

\section{Funções de confiança}

Na redação originária do dispositivo a expressão funções de confiança significava o mesmo que atividades gratificadas. O termo havia sido constitucionalizado para justificar os baixos salários, como é o caso dos datilógrafos e dos antigos 
'extranumerários', os quais não ocupavam cargos de provimento efetivo, nem cargos de provimento em comissão.

A EC n.19/98 pressupõe que, a partir de 4 de junho de 1998, as funções de confiança sejam exercidas "exclusivamente por servidores ocupantes de cargo efetivo", ou seja, pelos concursados.

A ressalva abrangerá também aqueles que desempenhavam, antes mesmo da edição da EC n.19/98, funçōes de confiança (atividades gratificadas), v.g., as inúmeras chefias de divisão em hierarquia de carreira, e que ingressaram no serviço público nos moldes do sistema passado, sem ocuparem cargos de provimento efetivo, nem cargos de provimento em comissão.

Quanto aos titulares de funções de confiança, não há que se falar em direito adquirido, porquanto tais sujeitos não possuem estabilidade - garantia constitucional que enseja a permanência do concursado nos quadros administrativos do Estado. O status de estável só pode ser conferido a quem faz concurso público de provas ou de provas e títulos (CF, art. 37, II), exigindo-se, ainda, como condição de sua aquisição, a avaliação especial de desempenho por comissão instituída para esse fim (CF, art. $41, \S 4^{\circ}$ ). Como os detentores de funções de confiança não ingressaram no serviço público através de concurso, jamais serão estáveis.

\section{Percentuais mínimos previstos em lei: inovação da EC n.19/98}

A EC n. 19/98 sistematizou a disciplina dos cargos em comissão. Procurou, assim, combater os excessos e os abusos, tão comuns à Administração brasileira.

Ao designar os "percentuais mínimos previstos em lei" para a ocupação de cargos em comissão por servidores de carreira, o legislador reformador eliminou a regra de que os cargos de comissão e funções de confiança deveriam ser exercidos preferencialmente por tais servidores.

De fato, a inovação se afigura, positiva, num primeiro momento, porque "tirar da Constituição uma palavrota hedionda: 'preferencialmente' que atrapalha a vida do Brasil, impedindo que tenhamos um serviço público profissional e sério. Com efeito, no artigo em que se declara que todos os cargos em comissão e as funções de confiança serão exercidos por servidores de carreira, admitidos por concurso, aquela palavrota permite a senadores, governadores e outras eminências, nomear quem bem queiram. Isso só se faz no Itamaraty, no Banco do Brasil e no Tribunal de Contas da União. Por isso, têm serviços públicos mais limpos e eficazes" (Darcy Ribeiro, Jornal do Brasil, set. 1996).

VII - o direito de greve será exercido nos termos e nos limites definidos em lei específica;

Dispositivo original: $V I I-o$ direito de greve será exercido nos termos e nos limites definidos em lei complementar.

Aqui contém outra inovação constitucional, inexistente nas constituições pretéritas, pois foi o Texto Maior de 1988 que primeiro autorizou o servidor público a se valer do direito de greve, como instrumento de reivindicação de suas prerrogativas. 
A EC n.19/98 propôs que a regulamentação do direito de greve seja feita através de lei ordinária, e não lei complementar, como estava na redação originária do inciso em epígrafe.

O objetivo foi combater a inércia do legislador, que, desde a promulgação do Texto de 1988, não editou a lei complementar almejada. Parece-nos, entretanto, que a letargia legislativa não será sanada a curto prazo, porque, mesmo sendo matéria imprescindível ao regime democrático, não existe o interesse de se expedir tal regulamentação, sob o argumento de que existe a Lei 7.783/89, que já dispõe sobre o exercício da greve em atividades essenciais.

$\mathrm{X}-$ a remuneração dos servidores públicos e o subsídio de que trata o $\S 4^{Q}$ do art. 39 somente poderão ser fixados ou alterados por lei específica, observada a iniciativa privativa em cada caso, assegurada revisão geral anual, sempre na mesma data e sem distinção de indices;

Inciso original: $X-$ a revisão geral da remuneração dos servidores públicos, sem distinção de indices entre servidores públicos civis e militares, far-se-á sempre na mesma data.

\section{A categoria dos subsídios}

Na EC n.1/69 - que alterou profundamente a Constituição de 1967 - os subsídios vinham previstos nos arts. 33 e 44, VII. Eram dirigidos aos Deputados, Senadores e ao Presidente da República. Através da Lei Complementar 25/75, estenderam-se aos Vereadores.

Com a promulgação do Texto de 1988 , a categoria dos subsídios foi eliminada da nossa normativa constitucional, não mais consistindo critério aferidor da remuneração dos agentes públicos.

A reforma administrativa, contudo, trouxe os subsídios de volta. O equívoco, do ponto de vista terminológico, foi lamentável, porque eles tinham sido banidos do nosso ordenamento jurídico pela manifestação constituinte originária de 1988 , no intuito de se dar um novo regramento aos estipêndios parlamentares.

Etimologicamente, 'subsídio' significa simples auxílio, subvenção, sem caráter remuneratório, pelo desempenho de função pública relevante. Com o tempo, ele passou a assumir caráter remuneratório, dado que o eleito sobrevivia, juntamente com a sua família, com a quantia angariada a título de subsídio, enquanto estivesse exercendo o mandato.

Ao eliminá-lo na redação originária da Constituição vigente, o constituinte pretendeu acabar com o sentido de mero achego, socorro, ajuda, que a expressão suscita, pois 'subsídio', do latim subsidium, remonta à idéia de quantia subscrita, gente que vem em socorro, tropa auxiliar. Acontece, porém, que nenhum agente público que quer ver a importância percebida pelos serviços que presta como mero auxílio, ajuda, socorro, achego.

Claro que a EC n.19/98 ressuscitou o termo não no seu sentido originário de ajuda, socorro, auxílio. Pretendeu, na realidade, enfatizar o caráter retributivo e 
alimentar do instituto. Daí ter substituído, em certos passagens do articulado constitucional, as palavras remuneração e vencimentos, por subsídios, no intuito de reforçar a idéia de que a importância paga, em parcela única pelo Estado, a certas categorias de agentes públicos, não poderá exceder a quantia mensal, percebida, em espécie, por um Ministro do Supremo Tribunal Federal.

Como, a rigor, a EC n. $19 / 98$ só atinge uma parte dos agentes públicos persistirá, simultaneamente, o regime de subsídios e o regime de remuneração ou vencimentos, implantado desde a feitura do Texto de 1988.

\section{Fixação por lei específica}

A EC n.19/98 suprimiu a determinação geral da remuneração dos servidores públicos civis e militares, na mesma data. Com efeito, a redação original desse inc.X, do art.37, usava de propósito o termo remuneração, no intuito de abranger todos os valores integrantes da retribuição dos civis e militares, para que nenhuma parcela ficasse de fora da identidade dos índices. Isto gerava distorções, porque dava margem a vantagens inexplicáveis.

Tanto a remuneração como o subsídio só poderão ser fixados ou alterados, a partir de agora, por lei ordinária determinada para esse fim. Excluem-se, pois, a possibilidade do uso de medidas provisórias, bem como a adoção de resoluções administrativas.

Complementam o entendimento da alteração em análise os arts. 37, XI; 39, § 40; 48, XV; 49, VII e VIII; 51, IV; 52, XI; 93, V; 96, II, $b ; 127$, § 20; 128, § $5^{\circ}$ e 169, § $1^{2}$.

$\mathrm{XI}$ - a remuneração e o subsídio dos ocupantes de cargos, funções e empregos públicos da administração direta, autárquica e fundacional, dos membros de qualquer dos Poderes da União, dos Estados, do Distrito Federal e dos Municípios, dos detentores de mandato eletivo e dos demais agentes políticos e os proventos, pensões ou outra espécie remuneratória, percebidos cumulativamente ou não, incluidas as vantagens pessoais ou de qualquer outra natureza, não poderão exceder o subsídio mensal, em espécie, dos Ministros do Supremo Tribunal Federal;

Dispositivo original: $X I$ - a lei fixará o limite máximo e a relação de valores entre a maior e a menor remuneração dos servidores públicos, observados, como limites máximos e no âmbito dos respectivos poderes, os valores percebidos como remuneração, em espécie, a qualquer título, por membros do Congresso Nacional, Ministros de Estado e Ministros do Supremo Tribunal Federal e seus correspondentes nos Estados, no Distrito Federal e nos Territórios, e, nos Municípios, os valores percebidos como remuneração, em espécie, pelo Prefeito;

\section{Teto das remunerações e subsídios}

O dispositivo, proveniente da EC n.19/98, traz o limite máximo da remuneração e do subsídio - o teto - dos ocupantes de cargos, funções e empregos públicos da administração direta, autárquica e fundacional, dos membros de qualquer dos Poderes das entidades administrativas, dos detentores de mandato eletivo e dos demais agentes políticos. 
Tal medida visou dar maior transparência e uniformidade no tratamento dos dinheiros públicos, impossibilitando a concessão de vantagens através de resoluções administrativas, outrora expedidas em sentido contrário ao princípio constitucional da moralidade.

A providência afigura-se, em tese, correta, porque a EC n. $19 / 98$ pretendeu implantar um regime geral básico, criando a categoria dos 'subsídios'. Estes, segundo os proponentes da alteração constitucional, serviriam para acabar com aquelas vantagens e mais vantagens injustificadas, que, na maioria das vezes, iam sendo incorporadas cumulativamente ao vencimento padrão do servidor, distorcendo toda uma carreira.

Note que o empregado público continua a fazer jus aos direitos trabalhistas clássicos, como o décimo terceiro salário, o adicional noturno, o salário família etc., nos termos do art. $7^{\mathbf{0}}$ da Constituição.

Por outro lado, o 'subsídio' terá como limite máximo (teto) o que for percebido pelos Ministros do Supremo Tribunal Federal. O Executivo, o Legislativo, o Judiciário, o Ministério Público, a polícia, dentre outros, estão sujeitos a esse critério.

Noutro prisma, a política remuneratória dos servidores públicos deverá seguir o que for determinado por lei específica, assegurada a revisão geral anual, sempre na mesma data, e sem distinção de índices. Nesse ínterim, o Supremo Tribunal Federal, na $3^{\text {a }}$ sessão Administrativa, realizada em 24 de junho de 1998, deliberou, por sete votos a quatro, que não são auto-aplicáveis as normas do art.37, XI, e 39, $\S 4^{\circ}$, da Constituição, com a redação que lhes deu a EC n. 19/98, vencidos os Ministros Sepúlveda Pertence, Carlos Velloso, Marco Aurélio e Ilmar Galvão. Entendeu a maioria dos Ministros do Pretório Excelso que a fixação do subsídio mensal em espécie depende de lei formal, de iniciativa conjunta dos Presidentes da República, da Câmara dos Deputadns, do Senado Federal e do Supremo Tribunal Federal. Com efeito, por ser a definição de subsídio mensal matéria expressamente sujeita à reserva constitucional de lei eın sentido fcrınal, não assistiria competência àquela Colenda Corte de Justiça, para, mediante, ato declaratório próprio, dispor sobre essa matéria específica. E, até que se edite a lei definidora de subsídio mensal a ser pago a Ministro do Supremo Tribunal Federal, prevalecerão os limites máximos (tetos) estabelecidos para os Três Poderes da República, nos termos da redação originária do art.37, XI, da Constituição.

Em suma, enquanto nāo advier a lei em causa, ficará prevalecendo o seguinte critério: Poder Executivo - o limite máximo ou teto corresponderá à remuneração paga a Ministro de Estado; Poder Legislativo - o limite máximo ou teto corresponderá à remuneração paga aos Membros do Congresso Nacional; Poder Judiciário - o limite máximo ou teto corresponderá à remuneração paga, atualmente, a Ministro do Supremo Tribunal Federal.

\section{Abrangência do teto}

Pelo dispositivo em estudo, o teto abrange os que continuam sob o regime remuneratório hoje em vigor, como os que passam para o regime de subsídio. Nesse ponto, caberá aos juízes e Tribunais equacionarem a delicada questão do direito adquirido, porquanto o Texto de 1988 consolidou a primazia do princípio, que 
garante $\mathrm{o}$ respeito às situações jurídicas já consolidadas e incorporadas ao patrimônio individual do seu titular (art.5 $5^{\circ}, \mathrm{XXXVI)}$.

$\mathrm{O}$ teto independe do regime jurídico a que se submete o servidor (estatutário ou celetista), abrangendo os ocupantes de cargos, funções ou empregos públicos.

A abrangência do teto extende-se aos servidores da Administração direta, indireta e fundacional. No tocante às empresas públicas, sociedades de economia mista e subsidiárias, o teto somente as alcança se elas receberem recursos da União, dos Estados, do Distrito Federal e dos Municípios para pagarem despesas de pessoal ou de custeio (art.37, $\S 9^{\circ}$ ).

Ao aduzir que o teto é o mesmo para os servidores dos Poderes da União, dos Estados, do Distrito Federal e dos Municípios, dos detentores de mandato eletivo e dos demais agentes políticos, a EC n.19/98 teve em vista os arts. 27 , $\$ 2^{\circ}$ e 29 , VI. Esses dispositivos tratam dos subsídios dos Deputados e Vereadores. Quanto aos primeiros, o limite do que percebem não pode ultrapassar $75 \%$ daquele estabelecido, em espécie, para Deputados Federais. No tocante aos segundos - os vereadores o limite de suas remunerações não pode exceder $75 \%$ do valor fixado para Deputados Estaduais.

O teto abrange os proventos dos aposentados e a pensão devida aos dependentes do servidor falecido.

Note-se a vedação contida no dispositivo : "outra espécie remuneratória". O objetivo foi impedir formas de remunerações que excedam o limite máximo permitido, que é a quantia percebida por um Ministro do Supremo Tribunal Federal.

O servidor que estiver em regime de acumulação sujeitar-se-á, segundo o discurso constitucional, a um teto único que abrange a soma dupla da retribuição pecuniária. Nisto surgirá um grande problema: aqueles servidores, que já estavam prestando seus serviços em mais de um cargo, emprego ou função, ficarão sem receber a remuneração total, correpondente às atividades desempenhadas? A propósito, ressalte-se o disposto no art.39, $\S 3^{\circ}$, que manda estender determinados benefícios do art. $7^{\circ}$ da Constituição.

A expressão "incluídas as vantagens pessoais ou de qualquer outra natureza" retrata a preocupação de se evitar o que ocorria na redação originária do dispositivo, a qual possilitava os Estados e Municípios fixarem subtetos. Com a nova fórmula, o teto não poderá sofrer variações, sendo igual para todos os servidores, em todos os níveis de governo. Logo, as vantagens pessoais incluem-se no limite máximo de remuneração, dentre outras 'adições salariais'.

XIII - é vedada a vinculação ou equiparação de quaisquer espécies remuneratórias para o efeito de remuneração de pessoal do serviço público;

Dispositivo original: XIII - é vedada a vinculação ou equiparação de vencimentos, para o efeito de remuneração de pessoal do serviço público, ressalvado o disposto no inciso anterior e no art. $39, \S I^{Q}$.

Impedimento de adições injustificáveis

A EC n. 19/98 excluiu a ressalva existente na redação originária do inciso, a qual estatuía a igualdade de vencimentos para os cargos e atribuições iguais entre Poderes, nos termos do anterior art.39, $\S 1^{2}$, agora totalmente reestruturado. 
XIV - os acréscimos pecuniários percebidos por servidor público não serão computados nem acumulados para fins de concessão de acréscimos ulteriores;

Dispositivo original: XIV - os acréscimos pecuniários percebidos por servidor público não serão computados nem acumulados, para fins de concessão de acréscimos ulteriores, sob o mesmo título ou idêntico fundamento;

Amplią̧ão da incidência recíproca

A EC n. 19/98 ampliou o campo de vedação do inc.XIV, dirigido aos acréscimos pecuniários percebidos por servidores. Para tanto, foi eliminada a expressão "sob o mesmo título ou idêntico fundamento".

XV - o subsídio e os vencimentos dos ocupantes de cargos e empregos públicos são irredutíveis, ressalvado o disposto nos incisos XI e XIV deste artigo e nos arts. $39, \S 4^{\circ}, 150$, II, 153 , III, e $153, \S 2^{2}$, I;

Dispositivo original: $X V$ - os vencimentos dos servidores públicos, civis $e$ militares, são irredutíveis e a remuneração observará o que dispõem os arts. 37, $X I, X I I, 150, I I, 153, I I I$, e 153, $\$ 2^{o}, I$;

A EC n.19/98 manteve o princípio da irredutibilidade, que já estava presente na redação original do dispositivo, agora atualizado pela reforma administrativa.

Observe-se que a ressalva prevista na última parte do inciso não fere o princípio da irredutibilidade. Incluíram-na aí pelos seguintes motivos:

$\left.1^{g}\right)$ para não se invocar a irredutibilidade de vencimentos no intuito de se manter remunerações que superam o teto

Aqui o reforço do art. 29 da EC n. 19/98, que, a nosso ver, deve ser interpretado sem ir de encontro com o pórtico fundamental do direito adquirido (art. $5^{\circ}, \mathrm{XXXVI)}$, o qual prevalece sobre toda e qualquer situação: “Os subsídios, vencimentos, remuneração, proventos da aposentadoria e pensões e quaisquer outras espécies remuneratórias adequar-se-ão, a partir da promulgação desta Emenda, aos limites decorrentes da Constituição Federal, não se admitindo a percepção de excesso a qualquer título".

$\left.2^{\circ}\right)$ para não impedir a aplicação do inc. XIV, do art.37

$\mathrm{O}$ inciso XIV, do art.37 impede cálculos cumulativos de vantagens pecuniárias, precisamente para impedir que aqueles que receberem uma quantia superior ao limite máximo (teto), não se escudem no princípio da irredutibilidade, argumentando que não poderão ter a sua remuneração diminuída. Nessa hipótese, cremos que o direito adquirido deve ser resguardado, pois o discrimen se dirige, apenas, aos casos posteriores à data de promulgação da EC n.19/98, isto é, 04.06.1998.

Realmente, o pórtico do direito adquirido tem o objetivo de impedir que situações consolidadas, no tempo, não sejam modificadas, nem muito menos, suprimidas. Se não fosse assim as conquistas alcançadas ficariam destituídas de proteção, os direitos subjetivos estabilizados no patrimônio jurídico individual seriam supressos, porque a lei nova desconstituiria os efeitos jurídicos que outrora repercutiram, beneficamente, na vida dos homens.

$\left.3^{2}\right)$ para que seja observado o disposto no art. 37, X e XI

Nesse particular, assinala Maria Sylvia Zanella di Pietro: “a referência ao art. $39, \S 4^{2}$, cria dúvida de interpretação: a qual parte do dispositivo a que quis se referir 
o legislador: àquela que se refere ao subsídio como parcela única, vedada a percepção de qualquer outra vantagem, ou àquela que manda respeitar o disposto no art. $37, \mathrm{X}$ e XI? Teria sido intenção do legislador afirmar que a irredutibilidade dos subsídios não impede a diminuição ou mesmo extinção das vantagens hoje percebidas? Parece-me que não pode ser essa a interpretação cabível, porque, se assim fosse, estaria a norma contemplando diversidade de solução: para os que percebem pelo sistema atual, a irredutibilidade teria de respeitar as vantagens pecuniárias; para os que passarem para o sistema de subsídios, não haveria necessidade de respeitar o montante hoje percebido a título de vantagens pecuniárias. A norma conflitaria com o princípio da isonomia, consagrado no art. $5^{\circ}$, caput, e no sentido de que a regra da irredutibilidade tem de respeitar o disposto no art.37, X e XI" (O que muda na remuneração dos servidores? (os subsídios). $B D A$, jul.98, p.427).

$\left.4^{0}\right)$ para tutelar as situações previstas nos arts. $150, I I ; 153, I, \S 2^{\circ}$; e 153, II

$O$ princípio da irredutibilidade de vencimentos e subsídios fica matido em relação ao ditame da igualdade aplicado aos contribuintes, à incidência do imposto de renda, à observância da generalidade, da universalidade e da progressividade do imposto de renda, na forma da lei.

$\mathrm{XVI}$ - é vedada a acumulação remunerada de cargos públicos, exceto, quando houver compatibilidade de horários, observado em qualquer caso o disposto no inciso XI:

a) a de dois cargos de professor;

b) a de um cargo de professor com outro, técnico ou científico;

c) a de dois cargos privativos de médico;

Dispositivo original: $X V I-e ́$ vedada a acumulação remunerada de cargos públicos, exceto quando houver compatibilidade de horários:

a) a de dois cargos de professor;

b) a de um cargo de professor com outro técnico ou científico;

c) a de dois cargos privativos de médico;

Limite máximo do inciso $X I$

A partir da EC n.19/98, o sistema da acumulação de cargos públicos deverá respeitar o teto previsto no inciso IX desse art.37.

XVII - a proibição de acumular estende-se a empregos e funções e abrange autarquias, fundações, empresas püblicas, sociedades de economia mista, suas subsidiárias, e sociedades controladas, direta ou indiretamente, pelo poder público;

Dispositivo original: XVII - a proibição de acumular estende-se a empregos e funçōes e abrange autarquias, empresas públicas, sociedades de economia mista e fundações mantidas pelo Poder Público;

Alargamento do campo de abrangência da proibição de acúmulo

Com a EC n.19/98, a proibição de acúmulo passou a atingir as subsidiárias e sociedades controladas, direta ou indiretamente pelo Poder Público. 
$X I X$ - somente por lei específica poderá ser criada autarquia e autorizada a instituição de empresa pública, de sociedade de economia mista e de fundação, cabendo à lei complementar, neste último caso, definir as áreas de sua atuação;

Dispositivo original: $X I X$ - somente por lei específica poderão ser criadas empresa pública, sociedade de economia mista, autarquia ou fundação pública.

A reserva de lei, expressa nesse inciso desde a sua primeira redação, é de grande importância, porque veio a preencher uma lacuna no Direito Constitucional positivo brasileiro, não obstante o fato de que a doutrina já apontava a sua existência implícita.

Inovação da EC n.19/98

A reforma administrativa firmou o posicionamento de que o regime jurídico das entidades mencionadas condicionam-se a uma lei específica, isto é, uma lei ordinária criada para fim determinado.

Pela nova redação do dispositivo, aliás confusa, parece-nos que a terminologia "neste último caso" foi inserida no sentido de restringir à lei complementar a definição das áreas em que devem atuar, apenas, as fundações, ficando de fora as autarquias, as sociedades de economia mista e as empresas públicas. Estas, pela letra do inciso, não estão sujeitas à incidência da lei complementar. Todavia, uma interpretação lógica do preceito, induz, necessariamente, a inclusão das três espécies institucionais como objetos de autorização.

$\S 3^{0}$ A lei disciplinará as formas de participação do usuário na administração pública direta e indireta, regulando especialmente:

$I$ - as reclamações relativas à prestação dos serviços públicos em geral, asseguradas a manutenção de serviços de atendimento ao usuário e a avaliação periódica, externa e interna, da qualidade dos serviços;

II - o acesso dos usuários a registros administrativos $e$ a informações sobre atos de governo, observado o disposto no art. 5้, X e XXXIII;

III - a disciplina da representação contra o exercício negligente ou abusivo de cargo, emprego ou função na administração pública.

Dispositivo original: $\S 3^{2}$ As reclamações relativas à prestação de serviços públicos serão disciplinadas em lei.

Técnicas de gestão foram aplicadas ao novo formato do $\S 3^{0}$, prescrito numa norma de eficácia contida.

A eficiência dos serviços públicos, bem como a participação do usuário na Administração direta e indireta, são assuntos que deverão ser tratados na lei (ordinária), através de critérios claros, para não inviabilizar o preceito constitucional.

Note-se que o preceito deixou a critério do legislador infraconstituional uma missão árdua, qual seja regular as reclamações dos destinatários dos serviços públicos em geral. Por outro lado, pontos nebulosos também ficaram à cargo de lei ordinária, como é o caso do acesso dos usuários aos registros administrativos e aos atos de governo, o combate à negligência ou abuso de cargo, emprego ou função pública.

$\S 7^{0}$ A lei disporá sobre os requisitos e as restrições ao ocupante de cargo ou emprego da administração direta e indireta que possibilite o acesso a informações privilegiadas. 
Este parágrafo, acrescido ao Texto Constitucional pela EC n.19/98, possui fundamento, porque objetiva evitar o favorecimento de particulares, através de informações privilegiadas.

Deveras, tornou-se praxe entre nós a conhecida situação em que ex-ocupantes de cargos e empregos da Administração direta e indireta, após exonerarem-se ou desligarem-se do exercício regular de suas funções, transmitiam para a iniciativa privada dados privilegiados do Estado, em flagrante desrespeito ao pórtico da igualdade.

Tendo em vista, pois, o princípio de que as informações da Administração Pública devem ser levadas a quem quer seja indistintamente, sem preferências de nenhuma espécie, os depositários do poder de reforma constitucional acrescentaram no corpo de normas da Carta Maior o parágrafo em epígrafe.

A medida ética de garantir a todos o acesso isonômico de dados, deve respeitar o sigilo de informações, quando este for imprescindível à segurança da sociedade e do Estado.

Saliente-se que a norma embutida no parágrafo em tela não é auto-aplicável, remetendo ao legislador ordinário a tarefa de disciplinar os requisitos e as restrições da garantia constitucional. Nesse sentido, valerá como exemplo, o art.30 da Lei Federal 9.472/97, que dispõe sobre a organização dos serviços de telecomunicações: "Até um ano após deixar o cargo, é vedado ao ex-conselheiro representar qualquer pessoa ou interesse perante a Agência".

$\S 8^{0} \mathrm{~A}$ autonomia gerencial, orçamentária e financeira dos órgãos e entidades da administração direta $e$ indireta poderá ser ampliada mediante contrato, a ser firmado entre seus administradores e o poder público, que tenha por objeto a fixação de metas de desempenho para o órgão ou entidade, cabendo à lei dispor sobre:

I - o prazo de duração do contrato;

II - os controles e critérios de avaliação de desempenho, direitos, obrigaçōes e responsabilidade dos dirigentes;

III - a remuneração do pessoal.

\section{Contrato de gestão}

O dispositivo de eficácia contida trouxe o contrato de gestão. Gestão, do latim gestione, traduz o ato de gerir, de administrar, de gerenciar. Daí o preceito trazer a mensagem de que a autonomia gerencial, orçamentária e financeira dos órgãos e entidades da Administração direta e indireta se utilizem desse instrumento.

No ordenamento jurídico pátrio, a figura do contrato de gestão vem surgindo, paulatinamente. Basta ver a a Lei 9.637, de 15.05.1998, e a Medida Provisória 1.501, de 9 de outubro de 1997.

A Lei 9.637/98 deu margem aos debates sobre parceria entre nações, entre o Estado e a iniciativa privada, entre empresas concorrentres, entre moradores de um mesmo bairro, entre empregados e empregadores, com a participação nos lucros e com a função social atribuída à empresa. Tal quadro alicerça-se na idéia de fomentar as atividades relacionadas à atuação de entidades semipúblicas (art. $5^{\circ}$ ). Nesse as- 
pecto, colimou dar os primeiros passos para a implantação do chamado acordo de programa, figura adotada em outros países, admitindo formas de flexibilização o souplesse dos juristas franceses - com vistas a priorizar a negociação e a colaboração.

Quanto à MP 1.501/97, ela, ao inaugurar novo quadro de fomento público no Brasil, tomou como base o princípio da livre associação (art. $5^{\circ}, \mathrm{XVII}$ ), incentivando a criação de entes intermédios pela sociedade, a fim de desenvolverem atividades dirigidas a seis setores de interesse público: o ensino, a pesquisa científica, o desenvolvimento tecnológico, a proteção e preservação do meio ambiente, a cultura e a saúde. Essas entidades receberam o nome de organizações sociais de colaboração. A partir daí é que surgem os contratos de gestão, como instrumentos destinados a viabilizar a' formação de parcerias, tendo em vista o fomento e a execução de atividades públicas.

A denominação "utilizada na Medida Provisória - contrato de gestão - é, porém, inadequada, uma vez que a natureza jurídica das relações que se estabelecem entre o Estado e a organização social não são contratuais. Com efeito, não são pactuadas prestações reciprocas, resultantes do sinalagma, voltadas à satisfação de interesses de cada uma delas em separado, senão que ambas as partes ajustam prestações conjugadas, dirigidas à satisfação de um mesmo interesse público que lhes é comum. Está-se, portanto, diante de um ato administrativo complexo, também chamado de ato união, em que há solidariedade de interesses e, por isso, conjugação de vontades e de meios e não um contrato, em que há composição de interesses divergentes e, por isso, estabelecimento de reciprocidade de prestações" (Diogo de Figueiredo Moreira Neto. Organizações sociais de colaboração - descentralização social e Administração Pública não-estatal. RDA, 210:192).

Doutrinariamente, o contrato de gestão é uma figura enigmática. Do ponto de vista do preceito constitucional em epígrafe, a idéia que o preside se liga à tarefa de abrir possibilidades para a existência de um pacto jurídico entre os órgãos e entidades da administração direta e indireta com o Poder Público.

Nos termos do dispositivo constitucional, portanto, contrato de gestão é a relação jurídica oriunda de um acordo de vontades, firmado pelos administradores dos órgãos e entidades, com vistas à fixação de metas de desempenho. Logicamente, as partes obrigar-se-ão, de maneira recíproca, a cumprirem as prestações contrapostas, sem que nenhuma delas possa, de forma unilateral, alterar ou extinguir aquilo que foi avençado. É que o contrato de gestão, para ser contrato, deve possui os traços nucleares da consensualidade e da autoridade de seus termos. Sem isto, a interpretação do dispositivo constitucional se desligaria da teoria geral dos contratos, concebidos, tradicionalmente, para compor, de modo pacífico, os interesses, comuns dos contratantes.

O contrato de gestão seria realmente um contrato? Qual seu vínculo com os entes que estão surgindo para desincumbir-se de atividades estatais, isto é, as Agências Reguladoras, as Organizações Sociais de Colaboração e as Agências Executivas? Só o tempo responderá, pois a experiência é mais rica do que as suposições. Por enquanto, lembremos da realidade vivida em França, quando André de Laubadère 
relatava que a Administração Pública costumava celebrar vários tipos de contrato, nomeando-os a depender de cada caso, e, muitas vezes, até criavam novas espécies, v.g., os contratos administrados, sem falar daqueloutros que não se sujeitavam ao regime do direito público, nem ao regime do direito privado (Contratos de la administración pública, in: Contratos públicos, Universidad Nacional de Cuyo, 1986).

\section{Conteúdo do contrato de gestão.}

O contrato de gestão poderá ser estabelecido temporariamente, seguindo a tendência da Constituição (art.37, IX) e da legislação infraconstitucional (Lei 8.745/93). Caberá ao legislador ordinário atentar para esse fato, dispondo sobre o prazo de sua duração. Ademais, incumbir-lhe-á prever controles e critérios de avaliação de desempenho, sem ferir direitos, nem renegar as obrigações e responsabilidades dos dirigentes. $O$ critério para aferir a remuneração do pessoal, também deverá ficar aos cuidados da lei ordinária.

Atente-se para o fato de que a figura dos contratos de gestão jamais poderão romper com os institutos do concurso público e da licitação. Caso o legislador ordinário não atente para essa particularidade, estará violando, frontalmente, a manifestação constituinte originária de 1988. Por isso, as entidades não podem se eximir, por via de contrato de gestão, desses instrumentos cogentes e constitucionais.

Para entender-se a mudança operada no regime das licitações das empresas estatais é necessário lermos o art.22, XXVII, em conjunção com art. $173, \S 1^{\circ}$, III, da CF, ambos reformados pela EC n.19/98.

O art.22, XXVII, foi modificado pela EC 19/98. Ele trata da competência privativa para legislar sobre normas gerais. A partir da nova redação, as empresas públicas e sociedades de economia mista, para realizar licitações e celebrar contratos, não mais se submeterão ao preceitos estritos da Lei 8.666/93 (Estatuto jurídico das licitações e contratos). Reger-se-ão, a partir de agora, pelo art. 173, § 1º, III, o qual também foi reformulado, prevendo outra lei, especificamente voltada para as estatais e suas subsidiárias exploradoras de atividade econômica.

$\S 90 O$ disposto no inciso XI aplica-se às empresas públicas e às sociedades de economia mista, e suas subsidiárias, que receberem recursos da União, dos Estados, do Distrito Federal ou dos Municípios para pagamento de despesas de pessoal ou de custeio em geral".

Não obstante a redação extensa do inc.XI, o constituinte reformador quis explicitar que o limite remuneratório ou redutor constitucional, estende-se às entidades arroladas no parágrafo.

Art. 38. Ao servidor público da administração direta, autárquica e fundacional, no exercício de mandato eletivo, aplicam-se as seguintes disposições:

Dispositivo original: Art. 38. Ao servidor público em exercício de mandato eletivo aplicam-se as seguintes disposições:

Art. 39. A União, os Estados, o Distrito Federal e os Municípios instituirão conselho de política de administração e remuneração de pessoal, integrado por servidores designados pelos respectivos Poderes. 
Dispositivo uriginal: Art. 39. A Uniāo, os Estados, o Distrito Federal e os Municípios insti itiro, no âmbito de sua competência, regime jurídico línico e planos de carreira pari "s servidores da administração pública direta, das autarquias $e$ das fundações pulicas.

Fim do regime juridico único

A substituição da fórmula imperativa e geral do regime jurídico único poderá se afigurar útil, superando os obstáculos revelados pelo sistema anterior.

Utópico e mal implementado, o regime jurídico único alimentava o ideal de se tratar, isonomicamente, todos os servidores públicos no âmbito de cada ente, em nome de uma 'unidade administrativa' para todas as pessoas jurídicas de direito público.

Agora, retorna a possibilidade do regime celetista para as entidades políticas, autarquias e fundações, tal como era na Constituição de 1967, com a sua EC n.1/69. $O$ que se buscou foi alargar a tendência de se fomentar a execução indireta ou terceirização de atividades, em parceria com as organizações sociais (Lei 9.637/98). Por outro lado, o regime estatutário poderá ser repensado em relação ao aspecto contributivo, inclusive no que tange aos custos da aposentadoria

Resta saber se a idéia de administração colegiada, através do conselho de política de administração e remuneração de pessoal, servirá para atuar com seriedade, funcionando com autonomia, para produzir resultados concretos em cada esfera de competência.

" $\S l^{o}$ A fixação dos padröes de vencimento e dos demais componentes do sistema remuneratório observará:

I - a natureza, o grau de responsabilidade e a complexidade dos cargos componentes de cada carreira;

II - os requisitos para a investidura;

III - as peculiaridades dos cargos.

Dispositivo original: $\S I^{0} A$ Lei assegurará, aos servidores da administração direta, isonomia de vencimentos para cargos de atribuições iguais ou assemelhados do mesmo Poder ou entre servidores dos Poderes Executivo, Legislativo e Judiciário, ressalvadas as vantagens de caráter individual e as relativas à natureza ou ao local de trabalho.

\section{Subsídios para os servidores organizados em carreira}

O dispositivo em tela não impede a organização em carreira dos servidores em regime de subsídios. Aliás, essa situação constatada na reforma administrativa vem confirmada nos arts. $37, \S 8^{\mathbf{0}} ; 39, \S 2^{2} ; 93 ; 128, \S 1 \stackrel{0}{\mathbf{0}} ; 131, \S 2^{2} ; 132 ; 134$, parágrafo único.

Padrões de vencimento: regras para a fixação

As regras para a fixação dos padrões de vencimentos e os componentes do sistema remuneratório, foram delineadas pela reforma administrativa. Elas levaram 
em conta a correspondência entre vencimentos e cargos, bem como as peculiaridades de cada atividade.

O intuito foi o de simplificar as carreiras da Administração direta, autárquica e fundacional, a exemplo do vinha fazendo a Lei 9.650, de 27.05.1998, adotada pelo Banco Central.

Os critérios para a investidura deverão ser aferidos de acordo com o grau de responsabilidade e a complexidade dos cargos componentes de cada carreira, tendo em vista suas peculiaridades. O objetivo é a formação de quadros profissionais menos dispendiosos e mais eficientes, tendo em vista o poder de gasto das instituições.

$\S 2^{o}$ A União, os Estados e o Distrito Federal manterão escolas de governo para a formação $e$ o aperfeiçoamento dos servidores públicos, constituindo-se a participação nos cursos um dos requisitos para a promoção na carreira, facultada, para isso, a celebração de convênios ou contratos entre os entes federados.

Dispositivo original: $\S 2^{0}$ Aplica-se a esses servidores o disposto no art. $7^{0}, I V$, $V I, V I I, V I I I, I X, X I I, X I I I, X V, X V I, X V I I, X V I I I, X I X, X X, X X I, X X I I I$ e $X X X$.

\section{Escolas de governo}

O preceito, oriundo da reforma administrativa, traz as escolas de governo para aperfeiçoamento de servidores.

A idéia é positiva, porque visa estimular a formação do servidor, não sendo necessário maiores gastos para viabilizar o desígnio constitucional.

$\S 3^{o}$ Aplica-se aos servidores ocupantes de cargo público o disposto no art. $7^{\circ}$, $I V, V I I, V I I I, I X, X I I, X I I I, X V, X V I, X V I I, X V I I I, X I X, X X, X X I I$ e XXX, podendo a lei estabelecer requisitos diferenciados de admissão quando a natureza do cargo o exigir.

Parágrafo acrescido ao Texto de 1988 pela EC n.19/98.

O servidor que ocupe cargo ou emprego público - excluídos aqueles que exercem mandato eletivo - farão jus: ao décimo terceiro salário, adicional noturno, salário família, adicional de férias, remuneração por serviço extraordinário.

Ressalve-se que o dispositivo menciona, genericamente, os ocupantes de cargo público, sem fazer qualquer distinção quanto ao regime remuneratório. Significa que o preceito seguinte não exclui as vantagens do art. $7^{\circ}$, mencionado. Numa palavra, não se entrechocam o $\S 3^{\circ} \mathrm{com}$ o $\S 4^{\circ}$, do art.39. A interpretação conciliatória evidencia que a aplicação de uma parcela única, não impede o direito a certas vantagens, inclusive aquelas de natureza indenizatória, como as diárias e as ajudas de custo, as quais visam compensar o servidor pelas despesas causadas no exercício do cargo.

Outro caso, o qual recomenda interpretação conciliatória, e que se escuda no princípio do dever de indenizar a quem sofreu prejuízos causados por outrem, é o referente à sessão legislativa extraordinária do Congresso Nacional (art.57, § 7º). Mesmo os parlamentares percebendo parcela única (art.39, $\S 4^{\circ}$ ), nada obsta a previsão da parcela indenizatória não superior ao do subsídio mensal, em caso de convocação para sessão legislativa extraordinária. 
Vale anotar que o parágrafo afirma que a lei pode "estabelecer requisitos diferenciados de admissão quando a natureza do cargo o exigir". Tal determinação serve para solver certas pendências jurídicas em torno dos critérios editalícios para a feitura de certames públicos, tais como limites de idade, especificações de sexo ou altura mínima etc. Antes da reforma administrativa, era comum candidatos a concursos irem ao Judiciário, com base no art. $7^{\circ}, \mathrm{XXX}$, para questionarem a legalidade de certos editais de certames, os quais continham discriminações. Agora a diferenciação de critérios para cada cargo ou carreira, põe fim à dúvida de sua possibilidade.

$\S 4^{\circ} \mathrm{O}$ membro de Poder, o detentor de mandato eletivo, os Ministros de Estado e os Secretários Estaduais e Municipais serão remunerados exclusivamente por subsídio fixado em parcela única, vedado o acréscimo de qualquer gratificação, adicional, abono, prêmio, verba de representação ou outra espécie remuneratória, obedecido, em qualquer caso, o disposto no art. 37, X e XI.

Parágrafo acrescido à Constituição pela EC n.19/98, que trouxe o princípio da verdade remuneratória, pelo qual a remuneração deixa de ser um composto de múltiplas parcelas, para tornar-se um vencimento.

O elenco contido no dispositivo é exemplificativo. Dele podemos extrair os Agentes públicos que deverão ser remunerados por subsídios e os agentes públicos que poderão ser remunerados por subsídios.

Agentes públicos que deverão ser remunerados por subsídios

Membros dos Poderes Executivo, Legislativo e Judiciário da União, Estados, Distrito Federal e Municípios, bem como os Ministros de Estado, Secretários Estaduais e Municipais (art.39, $\S 4^{\text {Q }}$ ); Membros do Ministério Público (art.128, $\S 5^{\circ}$, I, c); integrantes da Advocacia-Geral da União, os Procuradores dos Estados e do Distrito Federal e Defensores Públicos (art.135); Ministros do Tribunal de Contas da União (art.73, § $3^{9}$ ); e Servidores Públicos Policiais (art.144, § $9^{9}$ ).

Agentes públicos que poderão ser remunerados por subsidios

Dentre os agentes públicos, alguns serão remunerados por subsídios facultativamente, porque tudo irá depender do critério do legislador de cada esfera de governo. É o caso dos servidores públicos organizados em carreira, à luz do que prevê o art.39, $\S 8^{0}$.

\section{Subsidio como parcela única}

Aqui a categoria dos subsídios é prevista como parcela única.

O que se pretendeu com a disposição em epígrafe foi eliminar uma situação muito comum, ocorrida na vigência da Carta de 1967, quando a fixação de subsídios dividia-se em duas partes, uma fixa e outra variável.

Sobremais, note-se a intenção de se acabar com o sistema remuneratório que vinha vigorando desde a promulgação do Texto de 1988. A partir de agora, as mesmas categorias de agentes públicos não poderão perceber o padrão fixado em lei mais as 
famosas 'vantagens pecuniárias previstas nos estatutos'. Daí o dispositivo vedar expressamente "o acréscimo de qualquer gratificação, adicional, abono, prêmio, verba de representação ou outra espécie remuneratória". Consequiência disso: para os agentes que recebem subsídios ficam derrogadas todas as normas infraconstitucionais que prevejam vantagens pecuniárias remuneratórias como parte da remuneração.

Quanto aos ocupantes de cargos em comissão, chefia, direção, assessoramento, a fim de serem remunerados de forma diferenciada, a lei deverá estabelecer, para cada um, o subsídio composto da parcela única.

$\S 5^{0}$ Lei da União, dos Estados, do Distrito Federal e dos Municípios poderá estabelecer a relação entre a maior e a menor remuneração dos servidores públicos, obedecido, em qualquer caso, o disposto no art. 37, XI.

\section{Vedação de subtetos}

Este parágrafo não abre a possibilidade de se estabelecerem subtetos, como aparentemente se poderia imaginar. $\mathrm{Na}$ realidade o próprio art.37, XI, já define, de forma unitária para todas as entidades político-aministrativas, o limite máximo de remuneração ou subsídio dos servidores.

\section{Remissão facultativa ao legislador}

O preceito em pauta outorga uma tarefa facultativa ao legislador. Apenas permite que sejam avaliadas as circunstâncias que podem autorizar, ou não autorizar, a feitura de lei para as entidades federativas estabelecerem uma relação entre a maior e a menor remuneração paga aos servidores públicos de cada nível de Governo.

Sintetizando, o próprio dispositivo constitucional remete ao legislador o dever de observar, em qualquer caso, o disposto no art. 37, XI. Significa que o teto máximo, aí previsto, vincula a atividade legislativa ordinária, que não poderá criar subtetos.

$\S 6^{0}$ Os Poderes Executivo, Legislativo e Judiciário publicarão anualmente os valores do subsídio e da remuneração dos cargos e empregos públicos.

$\mathrm{O}$ disposto no preceito é decorrência lógica do princípio da publicidade, para dar aos servidores uma idéia do que eles poderão perceber em suas atividades.

$\$ 7^{0}$ Lei da União, dos Estados, do Distrito Federal e dos Municípios disciplinará a aplicação de recursos orçamentários provenientes da economia com despesas correntes em cada órgão, autarquia e fundação, para aplicação no desenvolvimento de programas de qualidade e produtividade, treinamento e desenvolvimento, modernização, reaparelhamento e racionalização do serviço público, inclusive sob a forma de adicional ou prêmio de produtividade.

O preceptivo remete à responsabilidade dos entes administrativos à elaboração de lei para a aplicação de recursos orçamentários provenientes da economia com despesas correntes.

Trata-se de uma tentativa para estimular os entes políticos a diminuírem os seus gastos, recompensando os agentes públicos com adicional ou prêmio de produtividade. 
$\S 8^{\underline{a}}$ A remuneração dos servidores públicos organizados em carreira poderá ser fixada nos termos do $\S 4^{\underline{ }}$ ".

Aqui foi consignada uma faculdade, não um dever, para a aplicação do princípio da verdade remuneratória, consagrado no $\S 4^{\circ}$.

Art. 41. São estáveis após 3 (três) anos de efetivo exercício os servidores nomeados para cargo de provimento efetivo em virtude de concurso público.

Dispositivo original: Art. 41. São estáveis, após dois anos de efetivo exercício, os servidores nomeados em virtude de concurso público.

A EC $\mathrm{n}^{\mathrm{o}} 19 / 98$, no art.28, respaldou aqueles que estavam em período de estágio probatório antes da data da sua edição: $E$ assegurado o prazo de dois anos de efetivo exercicio para a aquisição da estabilidade aos atuais servidores em estágio probatório, sem prejuízo da avaliação a que se refere o $\$ 4^{Q}$ do art.4l da Constituição Federal.

\section{Estágio probatório na EC n.19/98}

A disposição constitucional em epígrafe traz a mensagem de que só os concursados adquirirão estabilidade. Isto porque os cargos de provimento efetivo qualificam-se como definitivos, pois logram o traço da fixidez. Constituem-se, pois, na maioria dos cargos públicos, sendo providos à luz do que determina o art.37, II, da Constituição.

O período compreendido para a realização do estágio probatório é de três anos. Eís uma novidade advinda da EC n.19/98, que mudou o art.41 do Texto Maior, ampliando o lapso de tempo do estágio probatório de dois para três anos (art.41).

Óbvio que tal reforma repercute na legislação infraconstitucional, inclusive na Lei $8.112 / 90$ (arts.20, caput, e 21), a qual previa o prazo de dois anos para a execução do estágio probatório.

É importante salientar que para fins de estágio probatório só se computa o tempo de nomeação efetiva na mesma Administração (Sobre suspensão do estágio probatório: $\S 5^{\circ}$, do art.20, da Lei 8.112/90, acrescido pela Lei n.9.527/97).

Não se leva em conta o tempo de serviço em outra entidade do Estado, nem o período de exercício de função pública a título provisório. A propósito, o Tribunal de Justiça de São Paulo entendeu que motivos de doença não são computados para o estágio, em se falando de tempo de exercício efetivo da função (TJSP, RJTJSP 129: 373).

Por outro lado, o estágio probatório inicia-se na data do exercício da função, findando-se com o término do prazo de três anos. Portanto, não é a data da posse do agente público que serve para se contar o início do estágio. A posse configura, unicamente, a aceitação do cargo pelo seu provável ocupante. É o exercício efetivo da atividade que marcará o verdadeiro começo da relação jurídica travada entre o Estado e o agente público.

O servidor em estágio probatório não está impedido de exercer cargos de provimento em comissão ou funções de direção, chefia ou assessoramento no órgão ou entidade de lotação. Porém, somente poderá ser cedido a outro órgão ou entidade para ocupar cargos especiais, cargos de provimento em comissão do Grupo-Direção 
e Assessoramento Superiores - DAS, de níveis 6,5 e 4 , ou equivalentes ( $\$ 3^{\circ}$, do art.20, da Lei 8.112/90, acrescentado pela Lei n. 9.527/97).

$\S I^{0} O$ servidor público estável só perderá o cargo:

I - em virtude de sentença judicial transitada em julgado;

II - mediante processo administrativo em que lhe seja assegurada ampla defesa;

III - mediante procedimento de avaliação periódica de desempenho, na forma de lei complementar, assegurada ampla defesa.

Dispositivo original: $\S l^{\underline{Q}} \mathrm{O}$ servidor público estável só perderá o cargo em virtude de sentença judicial transitada em julgado ou mediante processo administrativo em que lhe seja assegurada ampla defesa.

Perda da estabilidade

O parágrafo em destaque condiciona a perda da estabilidale a três critérios, dentre eles a avaliação periódica de desempenho.

Tal exigência, seria uma contradição à permanência definitiva no serviço público, prevista no caput desse art.41? Afigura-se-nos que não. Ora, a avaliação periódica de desempenho, jamais configura uma medida de arbítrio, nem se pode imaginá-la para esse fim. É em realidade, uma tentativa positiva para fazer valer o princípio da eficiência, incorporado pela EC n.19/98 no ordenamento jurídico brasileiro (art.37, caput).

Enfatize-se que o procedimento para a avaliação periódica de desempenho, deverá ser estatuído através de lei complementar, sendo assegurada ampla defesa para aqueles que se sentirem descriminados. Assim, ofensas ao pórtico da igualdade, não ficarão destituídas de amparo constitucional. Isto justifica a avaliação periódica em causa, a qual não pode ser vista como ato arbitrário da Administração, mesmo porque a legalidade é a pedra de toque da República Federativa do Brasil. Conseqüentemente, será inconstitucional a lei complementar que não atentar para esse fato, e o Judiciário, certamente, será convocado para apreciá-la.

$\S 2^{\underline{I}}$ Invalidada por sentença judicial a demissão do servidor estável, será ele reintegrado, e o eventual ocupante da vaga, se estável, reconduzido ao cargo de origem, sem direito a indenização, aproveitado em outro cargo ou posto em disponibilidade com remuneração proporcional ao tempo de serviço.

Dispositivo original: $\S 2^{Q}$ Invalidada por sentença judicial a demissão do servidor estável, será ele reintegrado, e o eventual ocupante da vaga reconduzido ao cargo de origem, sem direito a indenização, aproveitado em outro cargo ou posto em disponibilidade.

A prescrição constitucional decorre do inc.I, $\S 1^{\mathbf{9}}$, desse art.41.

$\S 3^{Q}$ Extinto o cargo ou declarada sua desnecessidade, o servidor estável ficará em disponibilidade, com remuneração proporcional ao tempo de serviço, até seu adequado aproveitamento em outro cargo.

Preceito advindo da EC n.19/98, que retoma a redação do art.100 da EC n.1/69. 


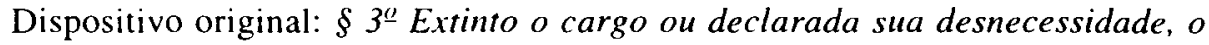
servidor estável ficará em disponibilidade remunerada, até seu adequado aproveitamento em outro cargo.

$O$ instituto da disponibilidade remunerada veio nesse preceptivo. Significa que a disponibilidade implica remuneração proporcional por tempo de serviço.

Trata-se de uma saída encontrada pelo poder constituinte derivado para colocar fim aos acirrados debates, oriundos da redação primeira do dispositivo, na qual a remuneração do servidor não poderia ser reduzida pela disponibilidade

$\S 4^{Q}$ Como condição para a aquisição da estabilidade, é obrigatória a avaliação especial de desempenho por comissão instituida para essa finalidade".

Parágrafo acrescido ao Texto de 1988 pela EC n.19/98, completando o disposto no $\S 1^{\circ}$, inc.III, desse art.41. A comissão referida deverá ter os seus contornos delimitados através de lei complementar. 